\title{
Evaluation of lifespan values of six tree taxa in city streets
}

\author{
Zsiláné-André, A. ${ }^{1}$, Zsila, L. ${ }^{2}$ \& Holb, I.J. ${ }^{1,3}$ \\ ${ }^{1}$ University of Debrecen, Institute of Horticulture P.O. Box 36, H-4015 Debrecen, Hungary \\ ${ }^{2}$ Zsila László Private Enterprise, Debrecen, Hungary \\ ${ }^{3}$ Plant Protection Institute, Centre for Agricultural Research, Hungarian Academy of Sciences, \\ P.O. Box 102, H-1525 Budapest, Hungary \\ Author for corresponding: Zsila-André, A. (zsilane.andre.aniko@gmail.com)
}

\begin{abstract}
Summary: The aim of this study was to evaluate lifespan values of trees in tree-row system in the streets of Debrecen in two years (2009 and 2017). Six selected taxa (Pyrus calleryana, Acer tataricum, Sorbus intermedia, Magnolia kobus, Acer platanoides and Crataegus $x$ lavalleei) were estimated for the following lifespan parameters: i) trunk diameter (cm), ii) tree crown size (m), iii) trunk status (in 0-5 grades), iv) tree crown status (in 0-5 grades), and v) estimated tree viability (in 0-5 grades). Our results showed that the largest were achieved for Pyrus calleryana and the lowest for Acer tataricum. The largest tree crown diameters were achieved for Acer platanoides and the lowest Magnolia kobus. The best trunk statuses by 2017 were achieved for Pyrus calleryana and the worst Crataegus x lavalleei. The best tree crown statuses by 2017 were achieved for Pyrus calleryana and the worst for Acer tataricum. The best estimated tree viability status was achieved for two taxa (Pyrus calleryana and Acer platanoides). Overall tree values were 2.73 times higher in 2017 compared to 2009. In summary, this study demonstrated the role of appropriate choice of tree taxa for a tree-row system under city street conditions.
\end{abstract}

Zsiláné-André, A., Zsila L., Holb, I. J. (2018): Evaluation of lifespan values of six tree taxa in city streets. International Journal of Horticultural Science 24(1-2): 25-27. https://doi.org/10.31421/IJHS/24/1-2./1543

Key words: tree-row system, tree measurements, green urban space

\section{Introduction}

Urban environment is highly dependent on the size, conditions and distributions of urban green areas within and around the cities. One of the known components of urban green areas is the tree-rows systems in streets. In these systems, trees are usually planted along a narrow line such as roads, railways, rivers and paths in rows (Schmidt, 2003).

Specific biological and ecological features are needed for tree species if they are decided to plant in narrow streets in towns. These trees need to adopt the city various ecological conditions (e.g. air pollution, road salting, small living space) and have to have linear trunk, have to grow fast, have to have long lifespan, have to have large root system, and have to have cheap tree maintenance. In addition, these tree taxa have to have small leaves and early leaf growth (Schmidt 1988).

There are several studies which describe tree species suitability of trees under city circumstances in Hungary (Nagy, 1980; Schmidt-Tóth, 2006; Schmidt, 2003; Schmidt-Varga, 2004; Szabó, 2015). Available tree taxa for city circumstances increased to double from the 1990's until 2004 in the market (Schmidt-Tóth, 2006) and the lists of these trees are published annually by the Hungarian Ornamental Gardener Association (Szabó, 2015; Szaller, 2013, 2017).

The aim of this study was to evaluate lifespan values of trees in tree-row system in the streets of Debrecen.

\section{Materials and methods}

The study was performed in the city of Debrecen, EasternHungary. In 2009 and 2017, tree-row system was evaluated by the modified methods of Radó (1981, 1999). Observations were made in both years on six selected taxa (Pyrus calleryana, Acer tataricum, Sorbus intermedia, Magnolia kobus, Acer platanoides, and Crataegus $x$ lavalleei). The following lifespan parameters were estimated: i) trunk diameter $(\mathrm{cm})$, ii) tree crown size $(\mathrm{m})$, iii) trunk status (in 0-5 grades), iv) tree crown status (in 0-5 grades), and v) estimated tree viability (in 0-5 grades). Trunk diameter was measured $1 \mathrm{~m}$ above the ground. Trunk status was assessed to represent the health and vitality of the trunk in a five grade scale from 0 to 5 . Tree value was calculated based on tree age, trunk diameter, and the grades of trunk and tree crown status. In case of parameter iii-v) a 5 scale grading system was used in which grade 0 represented very weak, grade 1 weak, grade 2 middleweak, grade 3 middle, grade 4 good, grade 5 excellent features of the observed parameter.

\section{Results and discussion}

Trunk diameter of the six tree taxa were between 4.9 and 9.8 $\mathrm{cm}$ and between 8.9 and $16.6 \mathrm{~cm}$ in 2009 and 2017, respectively (Figure 1). The largest trunk diameters were achieved for Pyrus calleryana and the lowest for Acer tataricum. The taxa of Acer tataricum, Magnolia kobus and Crataegus $x$ lavalleei had significantly lower trunk diameter from 2009 to 2017 than Pyrus, Sorbus or Acer platanoides species.

Tree crown diameter of the six tree taxa were between 0.66 and $1.5 \mathrm{~m}$ and between 2.4 and $3.7 \mathrm{~m}$ in 2009 and 2017, respectively (Figure 2). The largest tree crown diameters were achieved for Acer platanoides and the lowest for Magnolia kobus. Most taxa had twice to three times larger tree crown in 2017 than in 2009. Exceptions were Magnolia kobus and Crataegus $x$ lavalleei. 


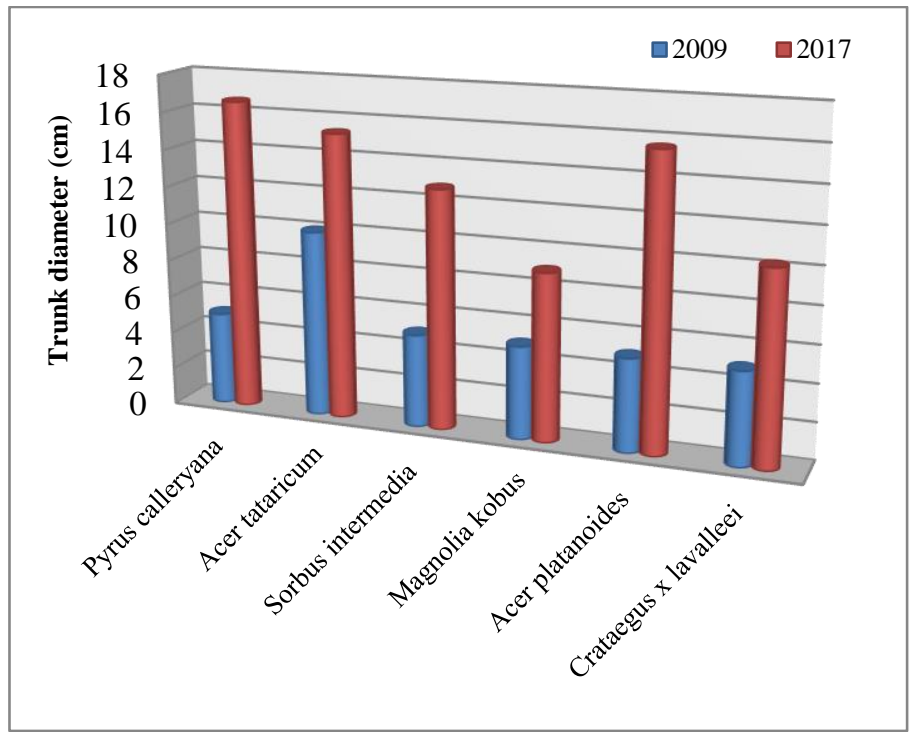

Figure 1. Trunk diameter of six tree taxa in streets of Debrecen in 2009 and 2017.

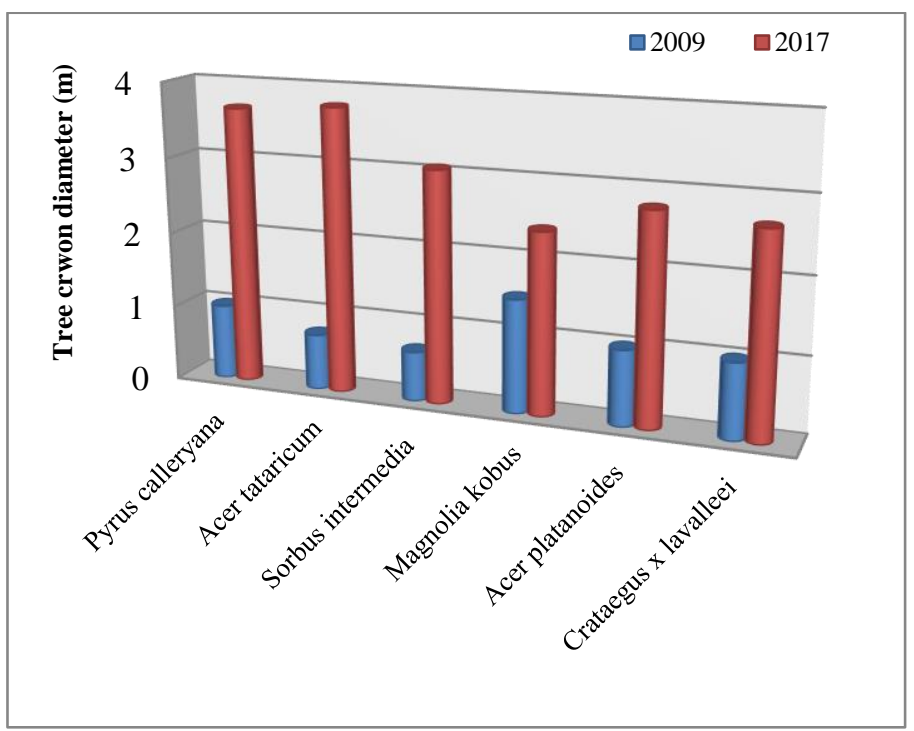

Figure 2. Tree crown diameter of six tree taxa in streets of Debrecen in 2009 and 2017.

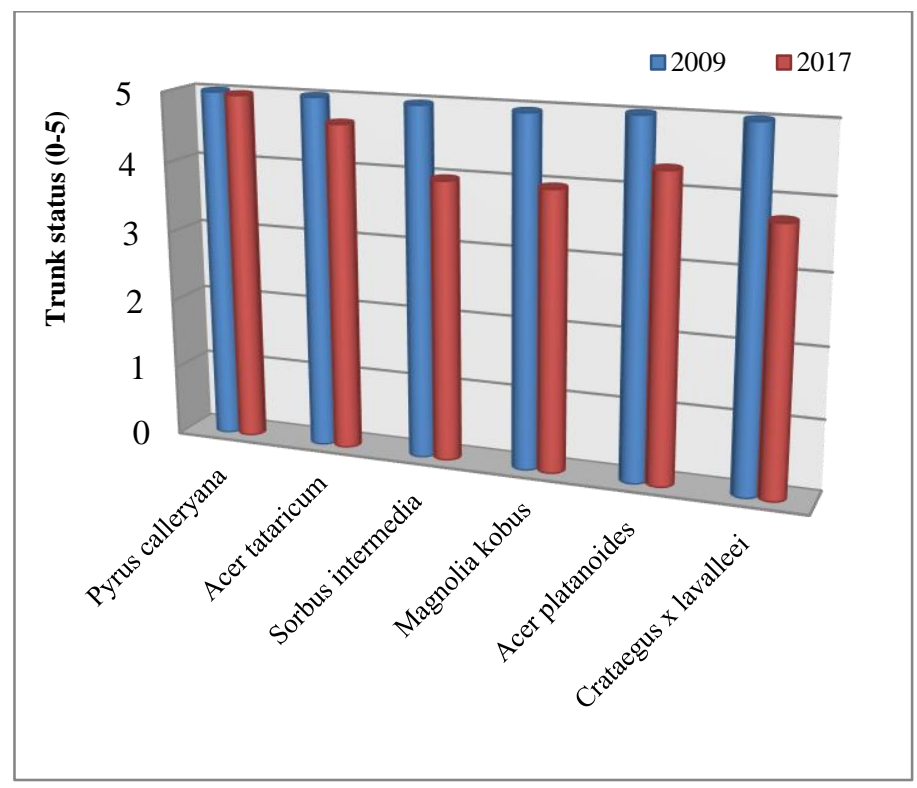

Figure 3. Trunk status of six tree taxa in streets of Debrecen in 2009 and 2017.

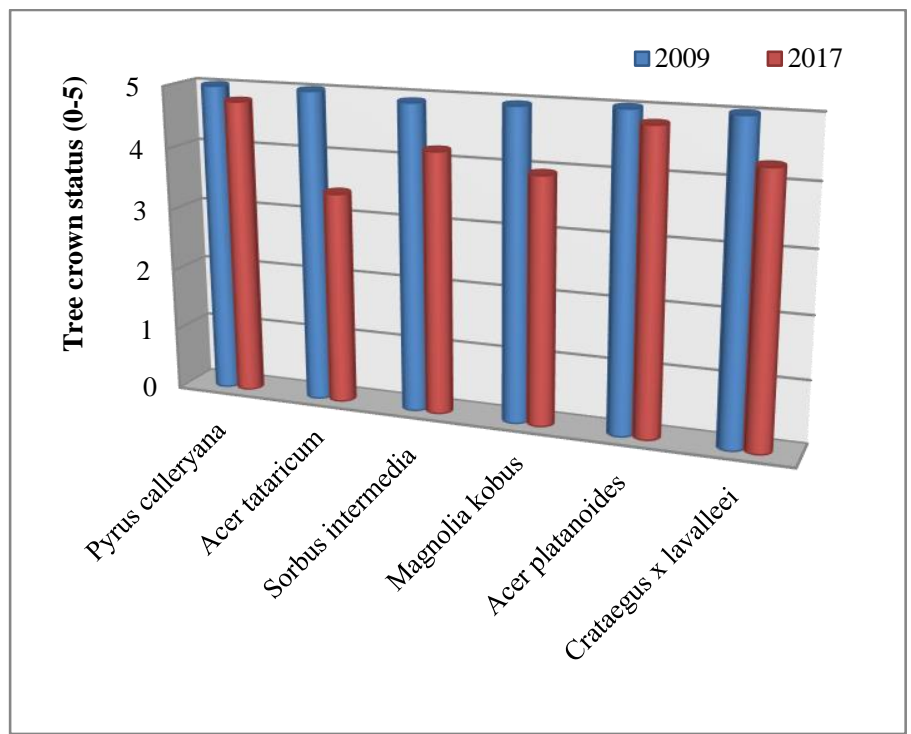

Figure 4. Tree crown status of six tree taxa in streets of Debrecen in 2009 and 2017.

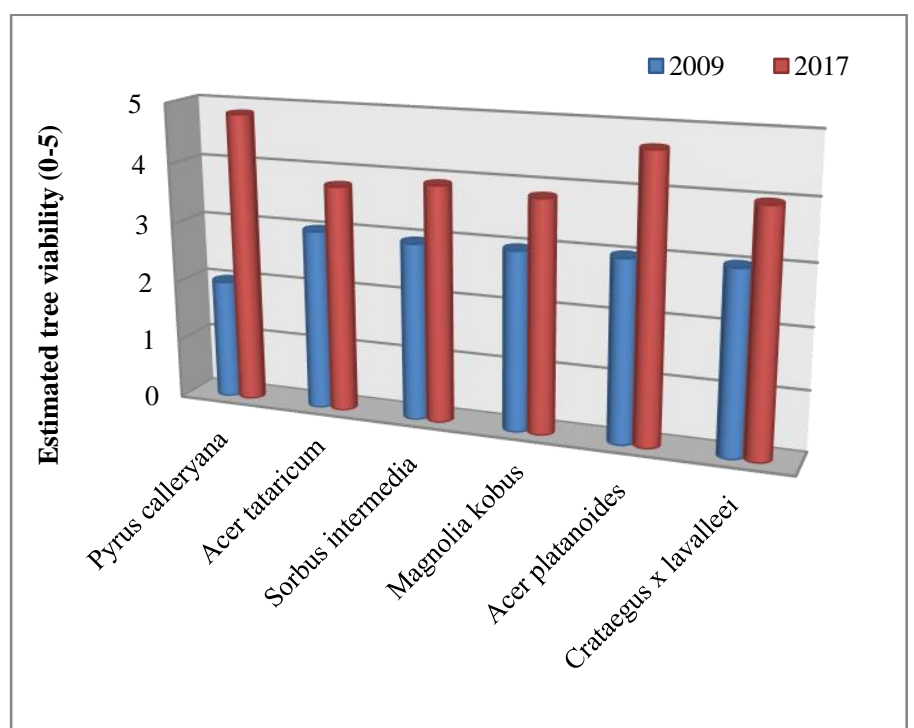

Figure 5. Estimated tree viability of six tree taxa in streets of Debrecen in 2009 and 2017

Trunk status of the six tree taxa were between 4.95 and 5.0 and between 3.7 and $4.9 \mathrm{~cm}$ in 2009 and 2017, respectively (Figure 3). The best trunk statuses by 2017 were achieved for Pyrus calleryana and the worst for Crataegus $x$ lavalleei. All other taxa showed a clearly worse trunk status from 2009 to 2017 than Pyrus calleryana species.

Tree crown status of the six tree taxa were between 4.9 and 5.0 and between 3.4 and $4.7 \mathrm{~m}$ in 2009 and 2017, respectively (Figure 4). The best tree crown statuses by 2017 were achieved for Pyrus calleryana and the worst for Acer tataricum.

Estimated tree viability of the six tree taxa were between 2.0 and 3.0 and between 3.7 and $4.8 \mathrm{~m}$ in 2009 and 2017, respectively (Figure 5). The best estimated tree viability status was achieved for two taxa (Pyrus calleryana and for Acer platanoides).

\section{Conclusions}

This study evaluated tree taxa compositions and tree lifespan in a tree-row system for narrow streets of Debrecen. The most successful taxa, among the evaluated six taxa, were 
Pyrus calleryana and Acer platanoides were for a tree-row system under city conditions. This study clearly showed that appropriate choices of tree taxa are essential for an establishment of tree-row system in narrow street conditions. Our study emphasizes the role of tree-rows systems as green areas in complex environmental improvement.

\section{Acknowledgements}

This research was partly supported by grants of the Hungarian Scientific Research Fund (K78399 and K108333) and the NKTH-OM-00227/2008 as well as by a by the European Union and the State of Hungary, co-financed by the European Social Fund in the framework of TÁMOP-4.2.4.A/ 2-11/1-2012-0001 'National Excellence Program' under project number A2-SZJ-TOK-13-0061. János Bolyai Research Fellowship awarded to Imre J. Holb. The research/thesis/dissertation is supported by the EFOP 3.6.1-162016-00022 project. The project is co-financed by the European Union and the European Social Fund.

\section{References}

Nagy, B. (1980): Díszfák, díszcserjék termesztése és felhasználása Mezőgazdasági Kiadó. ISBN 9632300874 pp. 455
Radó, D. (1981): Fák a betonrengetegben. Mezőgazdasági Kiadó, Budapest. ISBN 9632310586 pp.100

Radó, D. (1999): Bel- és külterületi fasorok EUmódszer szerinti értékelése. Lélegzet 1999/7-8: melléklet, Budapest.

Schmidt, G. (1988): A kert élő díszei - A növényalkalmazás tudománya. Mezőgazdasági Kiadó ISBN 963232465 X pp. 250

Schmidt, G. (2003): Növények a kertépítészetben Mezőgazda Kiadó ISBN 9632860624 pp.525

Schmidt, G., Tóth, I. (2006): Kertészeti dendrológia Mezőgazda Kiadó ISBN 9632863186 pp.403

Schmidt, G., Varga, G. (2004): Famutató Sopron ISBN: 963 8669829 pp. 210

Szabó, K. (2015): Közterületi sorfák jegyzéke 2015 Magyar Díszkertészek Szövetsége

Szaller, V. (2013): Útmutató a fák nyilvántartásához és egyedi értékük kiszámításához Magyar Faápolók Egyesülete http://www.faapolok.hu/nincs-kategorizalva/egyesuletunk-ujkiadvanya-utmutato-a-fak-nyilvantartasahoz-es-egyediertekuk-kiszamitasahoz/

Szaller, V. (2017): Útmutató a vizuális és müszeres favizsgálatok elvégzéséhez és dokumentálásához Magyar Faápolók Egyesülete https://drive.google.com/file/d/1SNB3UcJgZ0t2XZn0SIJGbs4 neIwV2_ld/view 